\title{
LITOFÁCIES E PROVÁVEIS AMBIENTES DE SEDIMENTAÇÃO DO GRUPO SÃO ROQUE NA REGIÃO DE VOTORANTIM E SALTO DE PIRAPORA, SP
}

\author{
Paulo Cesar FERNANDES DA SILVA
}

\section{RESUMO}

O presente estudo teve como objetivo a descrição e caracterização de fácies sedimentares das rochas proterozóicas pertencentes ao Grupo São Roque, aflorantes na região que compreende as cidades de Votorantim e Salto de Pirapora e arredores (sudeste do Estado de São Paulo). O levantamento foi efetuado na escala 1:50.000, e incluiu uma análise geológico-estrutural que procurou dar suporte ao entendimento da distribuição espacial das fácies sedimentares e do empilhamento estratigráfico. Quatro associações de litofácies foram reconhecidas na área de estudo, que da base para o topo correspondem a: $A$. associação siliciclástica basal, correspondendo a uma deposição em águas profundas predominantemente associada a uma sucessão turbidítica; $B$. associação siliciclástica intermediária, correspondendo a uma plataforma rasa de características progradantes; $C$. associação clasto-química transicional, aqui interpretada como uma transição de ambientes deposicionais de uma plataforma rasa para uma planície de maré mista (intramaré a intermaré); $D$. associação carbonática impura superior, representando as porções mais proximais e superiores de uma planície de maré (intermaré a supramaré). Estas associações foram informalmente correlacionadas às subdivisões estratigráficas sugeridas para o Grupo São Roque em trabalhos anteriores (particularmente as formações Estrada dos Romeiros, Voturuna e Pirapora).

Palavras-chave: rochas metamórficas, associações de litofácies, ambientes de sedimentação, Grupo São Roque.

\section{ABSTRACT}

The present study aims at characterizing the sedimentary facies of Proterozoic rocks of the São Roque Group that outcrop in the region including the cities of Votorantim and Salto de Pirapora and neighbourhood (southeast of the state of São Paulo, Brazil). These rocks were mapped at a scale of 1:50.000; included is a structural-geological analysis that supports the understanding of the spatial distribution of sedimentary facies and the stratigraphic units. Four associations of lithofacies and related depositional environments were recognized. They comprise from base to top: A. lower siliciclastic association, probably associated with deep-water sedimentation, mostly related to a turbiditic succession; B. intermediate siliciclastic association, corresponding to a shallow-water platform with prograding characteristics; C. transitional clastic-carbonate association, here interpreted as a transition from shallow platform deposition to a mixed carbonate tidal flat environment (subtidal to intertidal conditions); and D. upper impure carbonate association that may correspond to a tidal flat governed by tidal currents and related oscillatory movements (intertidal to supratidal conditions). These associations were informally correlated with previously proposed stratigraphic subdivisions of the São Roque Group in the region (namely Estrada dos Romeiros, Voturuna and Pirapora formations).

Keywords: metamorphic rocks, sedimentation settings, lithofacies associations, Grupo São Roque. 


\section{INTRODUÇÃO}

Apesar de serem relativamente numerosos os estudos efetuados em unidades metassedimentares proterozóicas do Estado de São Paulo, observa-se uma significativa carência de pesquisas cuja abordagem principal esteja voltada para a descrição das estruturas sedimentares ocorrentes e a caracterização de ambientes deposicionais correspondentes às referidas unidades.

Levando em consideração tal fato, o presente trabalho visou o estudo das fácies sedimentares e buscou interpretações acerca dos possíveis ambientes de sedimentação do Grupo São Roque na região que inclui as cidades de Votorantim e Salto de Pirapora e arredores, sudeste do Estado de São Paulo (Figura 1).

\subsection{Contexto regional}

Atendo-se apenas à evolução da designação da unidade como Grupo São Roque pode-se remontar ao trabalho de MORAES REGO (1930), que separou as rochas epimetamórficas do Complexo Cristalino aflorantes no Estado de São Paulo com a denominação de Série São Roque, termo este utilizado por diversos autores em trabalhos posteriores (e.g. KNECHT 1943; ALMEIDA 1955; FRANCO 1958). A ênfase em aspectos evolutivos de conteúdo geológico-estrutural pode ser observada nos trabalhos de HENNIES et al. (1967) e de HASUI et al. (1969), que reconheceram o controle tectônico sobre as unidades litológicas por meio de falhas, como a Falha de Taxaquara, mencionando a existência de três blocos tectônicos. O Bloco São Roque, enfocado no presente estudo, encontra-se entre os blocos Jundiaí e Embu, sendo delimitado a norte pela Zona de Cisalhamento Itu-Jundiuvira e a sul pela Zona de Cisalhamento Taxaquara.

COUTINHO (1972) propôs a reunião das rochas de idade pré-cambriana superior numa mesma unidade, argumentando a continuidade geográfica existente entre os grupos São Roque e Açungui. Tal proposição foi reforçada por HASUI (1973) ao estudar a geologia das folhas São Roque e Pilar do Sul. Posteriormente, HASUI (1975) reviu a conclusão anterior, reconhecendo a disposição das unidades em blocos justapostos e diferentes histórias deformacionais, reconsiderando o Grupo São Roque como unidade distinta. HASUI et al. (1976) realizaram a primeira tentativa de divisão estratigráfica formal da unidade, propondo duas formações: Boturuna, inferior, de natureza psamo-pelítica e com rochas vulcânicas intercaladas na base, e Piragibu, superior, composta por filitos rítmicos e quartzitos intercalados. Destacaram os autores que a tectônica transcorrente foi posterior ao metamorfismo regional, tendo inclusive controlado a intrusão de corpos graníticos.

Com base em critérios geológico-estruturais, HASUI \& SADOWSKI (1976) propuseram a subdivisão do Grupo Açungui em conjuntos litológicos, que caracterizaram como complexos (Pilar e Embu), assim como a sua separação do contexto do Grupo São Roque (submetido a apenas duas fases de dobramento, segundo os autores). O Complexo Pilar seria formado predominantemente por um conjunto de filitos e xistos (submetido a três fases de dobramento) e o Complexo Embu, por migmatitos e gnaisses migmatizados (contendo feições de dobramento invertido). Tal proposição foi adotada no Mapa Geológico do Estado de São Paulo (BISTRICHI et al. 1981) e Nota Explicativa (ALMEIDA et al. 1981). No entanto, CARNEIRO (1983) desenvolvendo estudos em áreas de afloramento do Grupo São Roque, entre o Pico do Jaraguá e a Serra dos Cristais (situada a nordeste da área enfocada no presente estudo e mais próxima da Cidade de São Paulo), reconheceu quatro unidades litoestratigráficas, afetadas generalizadamente por três fases de dobramento e submetidas a metamorfismo regional (em geral, no fácies xisto-verde). Reconheceu ainda que em determinados locais a foliação não se caracteriza como plano-axial, mas sim, paralela à estratificação reliquiar, diferentemente do indicado por HASUI \& SADOWSKI (1976). Tais conclusões foram corroboradas por BISTRICHI (1982) e SANTORO (1984). CARNEIRO (op.cit.) assinala também o aparecimento de dobras invertidas com provável transporte para SE, aspecto este observado em trabalhos posteriores (por ex. CARNEIRO et al. 1985, HACKSPACHER et al. 1991).

STEIN (1984) referiu-se aos metassedimentos situados ao sul da Falha de Taxaquara, nos arredores de Pilar do Sul, como Complexo pré-Açungui, distribuindo-os em três faixas que correspondem a filitos, xistos finos e xistos feldspatizados localmente migmatizados. Estas faixas exibem contatos transicionais, e teriam sido afetadas por até quatro estágios de metamorfismo regional. Posteriormente, CAMPOS NETO et al. (1990) estudando a geologia da Folha Pilar do Sul, na escala 1:25.000, reconheceram uma seqüência de metassedimentos turbidíticos a sudeste da cidade homônima e um domínio constituído por micaxistos e rochas ígneas prémetamórficas localizado na Serra dos Lopes e 
adjacências, ao sul da Zona de Cisalhamento Taxaquara. Esse conjunto de rochas foi correlacionado ao Grupo Açungui.

JULIANI et al. (1986) e JULIANI (1993) propuseram o uso do termo Grupo Serra do Itaberaba para aquela que seria a porção basal do Grupo São Roque, caracterizada por rochas metavulcânicas básicas com quimismo toleítico de natureza oceânica.

Retomando a abordagem regional, verifica-se que boa parte dos trabalhos existentes sugere uma evolução a partir de um quadro colisional no início do Neoproterozóico. Em HASUI (1985) e HASUI et al. (1989), a parte basal do Grupo Açungui, incluindo a porção Ribeira e o Complexo Embu, além do Grupo Serra do Itaberaba, são destacados como porções mais antigas relacionadas a uma mesma paleobacia. Essas porções são ou seriam afetadas por regime colisional do tipo himalaiano, considerando as faixas de supracrustais (Açungui Superior, Complexo Pilar do Sul) como prismas de acresção ou preenchimentos de bacias retroarco e antearco, e os granitóides como vinculados a arcos magmáticos das etapas pré- a pós-colisional. Para o Grupo São Roque e porções superiores restritas do Grupo Açungui, os referidos trabalhos assinalam que não é possível estabelecer se faziam parte de uma extensa seqüência supracrustal ou de embaciamentos independentes. Estas unidades, que atualmente ocorrem em faixas limitadas, poderiam representar porções remanescentes de pacotes mais extensos e espessos. O quadro tectônico regional estaria relacionado à articulação de blocos crustais, com deslocamento do Bloco Vitória de leste para oeste, produzindo cavalgamento deste em relação ao Bloco São Paulo em rampa oblíqua. Com este cavalgamento oblíquo de baixo ângulo, num primeiro estágio produziu-se desarticulação, imbricação e lenticularização dos corpos rochosos em estado plástico, desenvolvendo foliação milonítica com baixos mergulhos para SSE, paralela à sutura entre os blocos, e lineação de estiramento com direção ESE. Num estágio seguinte, o transporte de leste para oeste foi sendo gradativamente impedido, induzindo o surgimento de diversas zonas de cisalhamento dúctil e dúctilrúptil de alto ângulo com direção ENE-WSW, e criando outra lineação de estiramento. Diferentemente, HACKSPACHER et al. (1993) e HACKSPACHER (1994) sugeriram que a crosta transamazônica consolidada teria sofrido uma distensão há aproximadamente 1,8 Ga, dando início à deposição da seqüência vulcano-metassedimentar referente aos grupos Serra do Itaberaba e São Roque. Em seguida teria ocorrido a evolução tectono-metamórfica durante o
Ciclo Brasiliano, com o magmatismo atingindo seu máximo entre 0.8 e $0.7 \mathrm{Ga}$ a partir da fusão parcial da crosta continental inferior, associado a processos transtensivos e alojamento dos maciços granitóides Sorocaba e São Roque. O processo transpressivotranscorrente teria ocorrido em torno de $0.6 \mathrm{Ga}$, valor este interpretado por TASSINARI et al. (1988) como de resfriamento. Datações K/Ar efetuadas por estes últimos autores apresentaram idades de 1.52 Ga para a cristalização e metamorfismo de anfibolitos do Grupo Serra de Itaberaba e de 1.65 e 1.05 Ga para rochas metabásicas da região de Pirapora do Bom Jesus.

Trabalhos recentes proporcionaram uma série de informações geocronológicas acerca do Grupo São Roque e correlatos. Datações U-Pb em rochas metavulcânicas (frações zircão e monazita), efetuadas por HACKSPACHER et al. (1999, 2000), indicam que a deposição do Grupo São Roque teria ocorrido entre 0.628 e $0.607 \mathrm{Ga}$. Especificamente com relação às rochas aflorantes na área de estudo, resultados de datações $\mathrm{Sm} / \mathrm{Nd}$ apresentados por DANTAS et al. (2000) indicaram idades de $2.44 \mathrm{Ga}$ e de 1.86 Ga para as rochas-fonte, em metarritmitos e filitos do Grupo São Roque. Datações U-Pb em zircões provenientes de metandesitos basais indicam idades em torno de 1.4 Ga para o início da deposição de pelitos e vulcanismo do Grupo Serra do Itaberaba (JULIANI et al. 2000).

Aspectos sobre a sedimentação do Grupo São Roque foram destacados por BERGMANN (1988, 1992), que efetuou caracterização estratigráfico-estrutural de seqüência vulcano-sedimentar constituída por três unidades representativas de diferentes condições paleoambientais na região do Sinclinório de Pirapora, e por IG/SMA (1990), no mapeamento geológico da Folha Salto de Pirapora (1:50.000). Neste último trabalho, as interpretações sugerem que na porção ao sul da Zona de Cisalhamento de Pirapora teria ocorrido uma deposição em águas profundas por meio de fluxos gravitacionais de massa representados por correntes de turbidez (metarritmitos), às quais se intercalam processos de decantação num contexto de deposição pelágica ou hemipelágica (metargilitos e filitos). Ao norte da referida zona de cisalhamento, foi suposta uma deposição em sistemas de leques submarinos em posição relativamente distal, com maior variação de litofácies.

Para fins de analogia e correlação, foram utilizadas no presente trabalho, as designações de BERGMANN $(1988,1992)$ para as rochas do Grupo São Roque, cujo posicionamento estratigráfico foi tentativamente redefinido em HACKSPACHER et al. 
(1993) e HACKSPACHER (1994), com base na geologia da Folha Cabreúva. Três unidades principais são descritas por estes autores:

i) Formação Estrada dos Romeiros (base), compreendendo principalmente metarritmitos constituídos por intercalações de metarenitos feldspáticos e metapelitos, contendo laminações plano-paralelas, granodecrescência ascendente, laminações onduladas do tipo "climbing" e canais de preenchimento na base psamítica. A unidade consiste ainda de metarenitos feldspáticos a metarcósios, metassiltitos e filitos variados com passagens graduais para metarritmitos e metassiltitos.

ii) Formação Voturuna, compreendendo metassiltitos em contato basal gradativo com as rochas da unidade inferior, sobrepostos por quartzitos puros a micáceos, também feldspáticos, em contato abrupto.

iii) Formação Pirapora (topo), incluindo metabásicas e metacalcários, em contato abrupto com a unidade subjacente.

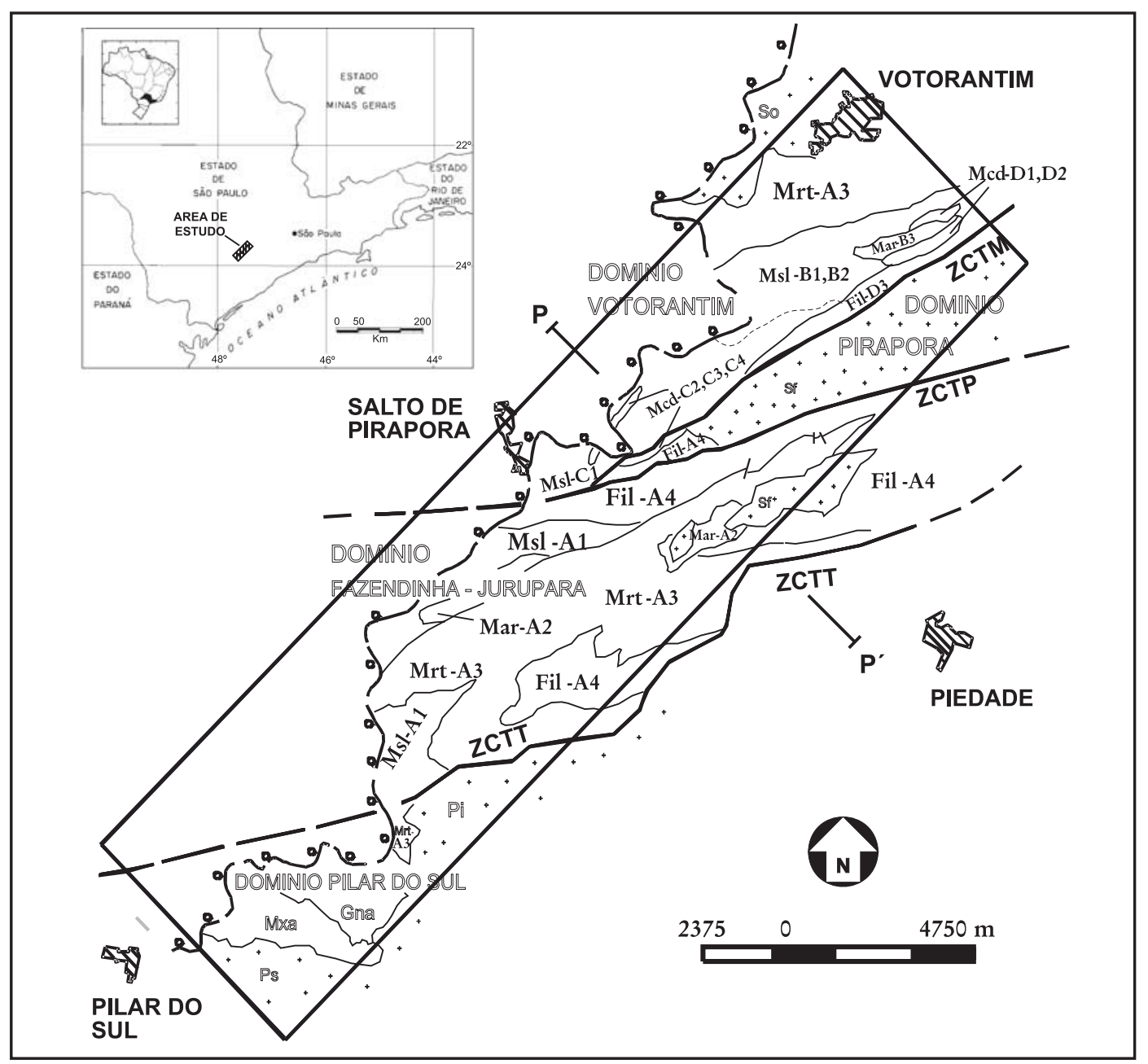

FIGURA 1 - Localização aproximada da área de estudo e mapa simplificado enfocando as litofácies identificadas e descritas no presente trabalho. Compartimentação da área em domínios estruturais delimitados por zonas de cisalhamento (ZCTM - Zona de Cisalhamento Transcorrente de Moreiras, ZCTP - Zona de Cisalhamento Transcorrente de Pirapora, ZCTT - Zona de Cisalhamento Transcorrente de Taxaquara). Litotipos associados ao Grupo São Roque: Mrt metarritmitos; Msl - metassiltitos e metargilitos; Mar - metarenitos quartzosos e feldspáticos; Mcd - metacarbonatos diversos; Fil - filitos diversos. Letras A, B, C e D acompanhando a nomenclatura dos litotipos e seguidas por numeração indicam as litofácies descritas (Tabela 1 e texto). Outros litotipos associados ao Grupo Açungui e rochas granitóides: Mxa - micaxistos; Gna - gnaisses félsicos passando a migmatitos; So - Maciço Sorocaba; Sf - Maciço São Francisco; Pi - Maciço Piedade; Ps - Maciço Pilar do Sul. A linha tracejada acompanhada por pontos configura o limite aproximado da Bacia do Paraná (rochas sedimentares do Subgrupo Itararé). (adaptado de FERNANDES DA SILVA 1997). 
É interessante notar que nas descrições de BERGMANN (1988) a Formação Estrada dos Romeiros seria constituída por metassiltitos e metarritmitos, com intercalações de rochas metabásicas e metacarbonáticas, e a Formação Pirapora compreenderia rochas metabásicas toleíticas e metacalcários de natureza algácea.

\subsection{Objetivos e escopo do presente trabalho}

O presente trabalho teve como objetivos principais:

a) o estudo de fácies sedimentares, empregando princípios e métodos interpretativos da análise de bacias, aqui adaptados a um pacote de rochas que foi submetido à deformação e metamorfismo;

b) cartografar a distribuição dos tipos litológicos identificando suas variações e relações espaciais, enfocando aspectos descritivos sobre sedimentação, considerando aspectos da tectônica regional e local e relações com eventos magmáticos;

c) analisar os pacotes rochosos enfatizando o reconhecimento e interpretação dos episódios deposicionais e processos envolvidos e, dentro do possível, reconstituir relações estratigráficas;

d) reconhecer os eventos deformativos, com o intuito de subsidiar possíveis reconstituições estratigráficas.

Considerando que uma fácies é um corpo de rochas com características específicas, no presente trabalho, o enfoque foi dado às características físicas e químicas da rocha, sendo apropriado o uso do termo litofácies (MIALL 1985). Uma litofácies deve ser idealmente uma rocha com características distintivas, formada sob certas condições de sedimentação, refletindo um processo ou ambiente particular. As fácies podem ser subdivididas em sub-fácies ou agrupadas em assembléias ou associações de fácies. As associações de fácies são grupos de fácies que ocorrem juntas e são consideradas como geneticamente ou ambientalmente relacionadas. Cada grupo de fácies pode ser identificado como uma associação distinta. A associação é capaz de prover evidências adicionais que tornam a interpretação ambiental mais fácil do que tratando cada fácies isoladamente (READING 1996).

Nesse sentido, a abordagem adotada no presente estudo levou em consideração os seguin- tes aspectos relativos aos metassedimentos do Grupo São Roque aflorantes na região: (1) determinados litotipos repetem-se com maior ou menor número de variações (composicionais e/ou texturais) ao longo da coluna ou seção vertical; (2) os litotipos analisados referem-se possivelmente a fácies e sistemas deposicionais contemporâneos. Tais aspectos reforçaram o uso de associações de litofácies como elemento de análise mais adequado para a investigação dos ambientes de sedimentação, incluindo processos e feições decorrentes, suas relações cronológicas, e possíveis conotações com o quadro estratigráfico regional.

\section{ASSOCIAÇÕES DE LITOFÁCIES}

O presente trabalho enfocou o conjunto de metassedimentos referido como Grupo São Roque, delimitado ao sul pela Zona de Cisalhamento de Taxaquara (ZCTT, Figura 1) e estendendo-se para norte com uma distribuição razoavelmente contínua até as proximidades da cidade de Votorantim. Registra-se ainda a incursão de corpos de rochas granitóides e de manchas de sedimentos fanerozóicos no trecho mencionado (BISTRICHI et al. 1981, IG/ SMA1990). Segundo FERNANDES DASILVA(1997), todo o conjunto de metassedimentos atribuídos ao Grupo São Roque teria sido afetado na área de estudo por três fases progressivas de deformação. A primeira fase $(D n)$, de natureza dúctil, corresponderia a uma cinemática de baixo ângulo, responsável por dobramentos locais a semi-regionais do acamamento sedimentar $\left(S_{0}\right)$, envolvendo o desenvolvimento da foliação tectono-metamórfica $(S n)$. As outras duas fases de deformação $(D n+1$ e $D n+2)$, dizem respeito a uma cinemática de alto ângulo com transição do caráter dúctil para dúctil-rúptil. A fase Dn+1 caracteriza-se pelo desenvolvimento de dobras (sinformes e antiformes) de estilo bastante variado sobre a foliação anterior ( $S n)$, com desenvolvimento local de foliação plano-axial $(S n+1)$, geralmente verticalizada, que evolui para uma foliação milonítica $(\mathrm{Sm})$ associada ao desenvolvimento de zonas de cisalhamento transcorrente de característica dúctil-rúptil. A fase Dn+2 representa os efeitos transpressivos tardios associados ao cisalhamento, caracterizando-se pela formação de dobras normais, suaves e abertas, que podem evoluir a dobras apertadas nas proximidades das zonas de cisalhamento transcorrente (Figura 2). Estas, por sua vez, constituem feições de dimensões quilométricas, que delimitam domínios estruturais, blocos ou compartimentos tectônicos (Votorantim, 


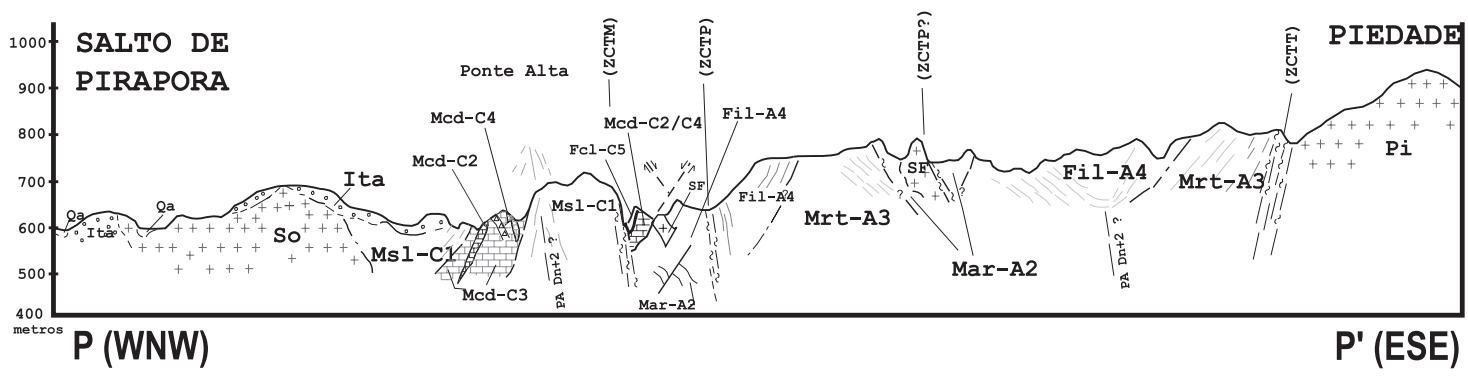

FIGURA 2 - Perfil geológico esquemático P - P' cortando a área de estudo no sentido WNW - ESE (aproximadamente perpendicular ao trend regional) e mostrando a relação espacial das unidades (litofácies aqui descritas e outros litotipos ocorrentes) entre as localidades de Salto de Pirapora e Piedade (vide localização na figura 1). Litotipos/litofácies associados ao Grupo São Roque: Mar-A2 - metarenitos quartzosos e feldspáticos; Mrt-A3 - metarritmitos; Fil-A4 filitos sericíticos e grafitosos; Msl-C1 - metassiltitos laminados; Mcd-C2 - metamargas laminadas e bandadas; Mcd-C3 - metadolomitos e metacalcarenitos dolomíticos bandados; Mcd-C4 - metacalcilutitos laminados e bandados. Rochas granitóides e outros litotipos: So - Maciço Sorocaba; Sf - Maciço São Francisco; Pi - Maciço Piedade; Ita - lamitos e arenitos do Subgrupo Itararé; Qa - sedimentos aluvionares. ZCTM - Zona de Cisalhamento Transcorrente de Moreiras; ZCTP - Zona de Cisalhamento Transcorrente de Pirapora; ZCTT - Zona de Cisalhamento Transcorrente de Taxaquara. Adaptado de FERNANDES DA SILVA (1997).

Pirapora, Fazendinha-Jurupará e Pilar do Sul, como ilustrado na figura 1), dentro dos quais os conjuntos de rochas foram menos afetados pelo regime de transcorrência. FERNANDES DA SILVA(1998) assinala que esse conjunto de metassedimentos teria sido ainda afetado por seis eventos de deformação rúptil de idade possivelmente meso-cenozóica.

No presente trabalho foi possível identificar e caracterizar quatro associações de litofácies distintas, provavelmente representando ambientes deposicionais diferentes, como sintetizado na tabela 1. As associações de litofácies identificadas na área de estudo foram correlacionadas tentativamente às unidades estratigráficas descritas por BERGMANN (1988, 1992) eHACKSPACHER (1994) mencionadas acima.

A relação entre litofácies e associações de litofácies é apresentada em seção vertical esquemática no item 3 (Figura 12). As espessuras aparentes, quando indicadas na seção vertical esquemática, foram estimadas a partir da distribuição em mapa e de perfis geológicos com integração de dados de poços tubulares profundos, procurando levar em consideração os efeitos produzidos pela tectônica. As relações espaciais entre as litofácies na porção central da área de estudo são ilustradas de forma esquemática no perfil geológico apresentado na figura 2. As associações de litofácies caracterizadas são descritas a seguir.

\subsection{Associação de litofácies A - siliciclástica basal}

A associação de litofácies A - siliciclástica basal compreende metassiltitos laminados, metarritmitos, metarenitos feldspáticos a arcosianos e algumas ocorrências de tipos quartzosos, filitos sericíticos e grafitosos, e eventuais níveis de metargilitos maciços.

A associação de litofácies siliciclástica basal foi observada em duas porções distintas da área de estudo. Ao norte, próximo a cidade de Votorantim, estendendo-se para SW, onde apresenta relações de contato pouco definidas (devido à cobertura de solos) com a associação de litofácies B sobrejacente, em condição de topo invertido estruturalmente. $\mathrm{Na}$ porção centro-sul (Domínio Fazendinha - Jurupará), onde ocupa uma grande extensão, exibe contatos abruptos definidos por zonas de cisalhamento transcorrente. Neste domínio, o limite norte é dado pela Zona de Cisalhamento de Pirapora (ZCTP, Figuras1 e 2) que provoca o truncamento dos trends faciológicos, justapondo associações de litofácies distintas. No limite sul, ocorre o mesmo tipo de situação envolvendo a Zona de Cisalhamento de Taxaquara (ZCTT, Figura1) e rochas que foram separadas do contexto do Grupo São Roque neste e em trabalhos anteriores, associadas provavelmente ao Grupo Açungui, conforme as descrições de HASUI \& SADOWSKI (1976), STEIN (1984) e CAMPOS NETO et al. (1990).

Cinco litofácies referentes à associação siliciclástica basal são descritas a seguir (Tabela 1, Figura 12).

- Metassiltitos laminados (Msl-A1, Figura 1). A litofácies corresponde às ocorrências ao sul e a su- 
deste de Salto de Pirapora (Domínio FazendinhaJurupará), com espessuras relativas aparentes entre 250 e 300 metros. Nos trechos citados são observadas rochas argilo-siltosas com cores de alteração, entre cinza castanho-avermelhado escuro a arroxeado muito característico, constituídas por níveis extremamente contínuos com espessuras inferiores a $2 \mathrm{~mm}$, configurando laminações plano-paralelas. Em direção ao topo da litofácies há um nítido incremento de níveis de metarenito muito fino (geralmente com espessuras de 1 a 15 mm). Ao sul da cidade de Salto de Pirapora, próximo ao contato com os metarenitos da litofácies sobrejacente (Mar-A2), são observadas laminações cruzadas de baixo ângulo do tipo climbing e de truncamento por ondas. São feições com dimensões decimétricas a milimétricas (espessura máxima dos foresets inferior a $3 \mathrm{~mm}$ ) que indicam topos normais para SE e, por vezes, fluxo combinado (alguns sets indicam a existência de duas direções aparentemente a $180^{\circ}$ ). Nas laminações cruzadas de baixo ângulo (Figura 3) observa-se que os contatos basais das camadas claras (silto-arenosas) são predominantemente bruscos, com a concavidade voltada para cima, exibindo truncamento angular das laminações internas pela camada escura subjacente (pelítica). Um pouco acima da referida porção, as camadas silto-arenosas permanecem com a concavidade para cima, entretanto, as laminações internas apresentam contatos basais mais tangenciais e gradativos. Embora sejam menos freqüentes, ainda no mesmo local, observam-se feições com convexidade voltada para cima, do tipo laminação cruzada truncada por ondas (Figura 4).

O padrão aparentemente bimodal observado em alguns casos nas estruturas sedimentares acima descritas não necessariamente representariam produtos de fluxos combinados. Por exemplo, as estruturas poderiam representar laminações cruzadas do tipo climbing, cujo corte em afloramento estaria aproximadamente perpendicular à direção da corrente (festões), ou poderiam ainda representar descontinuidades internas de foresets, relacionadas à base de estratificações cruzadas de maior ordem (COLLINSON \& THOMPSON 1989), mas que não puderam ser identificadas localmente.

- Metarenitos maciços a levemente estratificados (Mar-A2, Figuras 1 e 2). A litofácies está representada por "manchas" ou lentes de dimensões variáveis e espessuras aparentes estimadas em dezenas a uma centena de metros, aflorantes no trecho entre as Zonas de Cisalhamento de Pirapora (ZCTP) e de Taxaquara (ZCTT). Compreendem metarenitos predominantemente maciços com variações composicionais e granulométricas. Os tipos quartzosos apresentam grã levemente grossa a fina, como na ocorrência ao sul de Salto de Pirapora anteriormente mencionada, onde os metarenitos apresentam-se em termos conglomeráticos finos, contendo na base, clastos da litofácies A1 descrita acima (metassiltitos laminados), em granodecrescência ascendente (Figura 5). Os referidos clastos são angulosos a subangulosos, com dimensões inferiores a $5 \mathrm{~mm}$ de comprimento, distribuídos de maneira levemente orientada subparalelamente ao plano de acamamento. Os tipos feldspáticos são em geral mais grossos e estratificados, e apresentam-se freqüentemente deformados e associados à presença de zonas de cisalhamento transcorrente (Figura 2).

- Metarritmitos (Mrt-A3, Figuras 1 e 2). Esta litofácies predomina na associação A, assim como nas duas porções de área acima mencionadas (Domínios Votorantim e Fazendinha-Jurupará), possivelmente refletindo a estruturação tectônica regional. As espessuras aparentes estimadas indicam pacotes possivelmente superiores a $1000 \mathrm{~m}$. É cons-

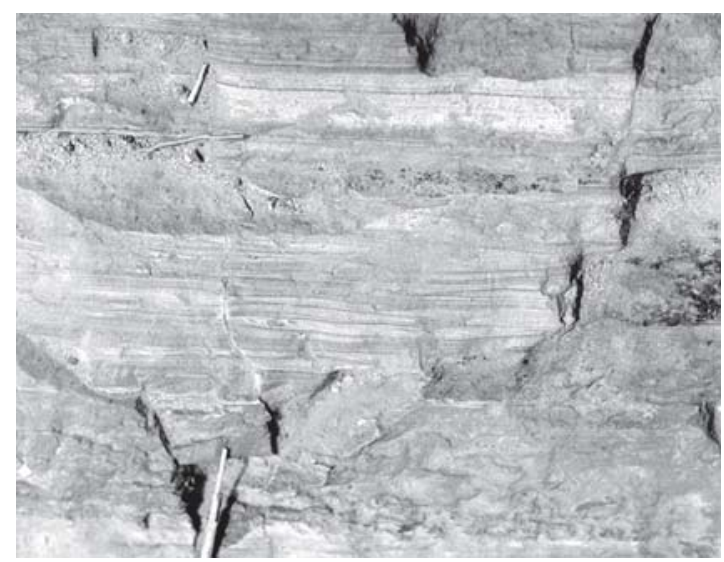

FIGURA 3 - Metassiltitos laminados (Msl-A1). Laminações cruzadas de baixo ângulo.

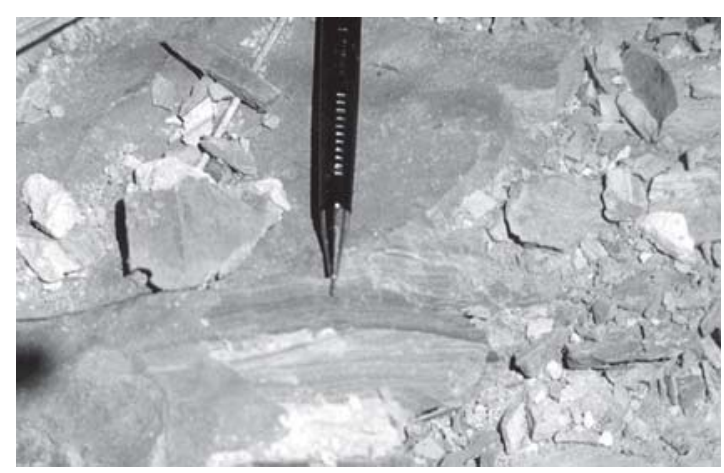

FIGURA 4 - Metassiltitos laminados (Msl-A1). Laminações cruzadas truncadas por ondas. 
tituída pela alternância de níveis psamíticos (cujas espessuras variam desde alguns centímetros até 2 metros) contendo metarenitos muito finos a médios, de composição predominantemente feldspática, e de níveis de metapelitos (metassiltitos, metargilitos, filitos), com espessura nunca excedendo 50-60 cm. Os níveis metareníticos apresentam contatos bruscos na base (onde são geralmente maciços), com granodecrescência normal ascendente em direção às porções pelíticas, marcando estratificação gradual que passa a plano-paralela. Laminações cruzadas de marcas onduladas cavalgantes (climbing), de dimensões milimétricas, ocorrem com pouca freqüência próximas à interface entre os níveis pelíticos e psamíticos, aspecto também reportado em IG/SMA (1990) na área de estudo e, em HACKSPACHER (1994) para ocorrências na Folha Cabreúva. Em localidades situadas a sudeste da área de estudo, essas feições indicam topos normais, ora para NW, ora para SE, com predominância desses últimos, provavelmente devido a dobramentos locais (conjunto de sinformes e antiformes atribuído à fase de deformação Dn+1). Ao norte, no Domínio Votorantim, próximo ao contato com os metassiltitos e metargilitos sobrejacentes da associação de litofácies B (descrita a seguir), os metarritmitos exibem finas estratificações onduladas (wavy bedding) indicando topos invertidos para SE, visto que o acamamento sedimentar original mergulha para NW no local.

- Filitos laminados a bandados (Fil-A4, Figuras 1 e 2). Esta litofácies tem nos filitos sericíticos seu principal constituinte, ocorrendo subordinadamente níveis ou variações laterais de filitos grafitosos. A distribuição desta litofácies na área de estudo está em grande parte associada à deformação provocada pelas zonas de cisalhamento transcorrente. Junto à

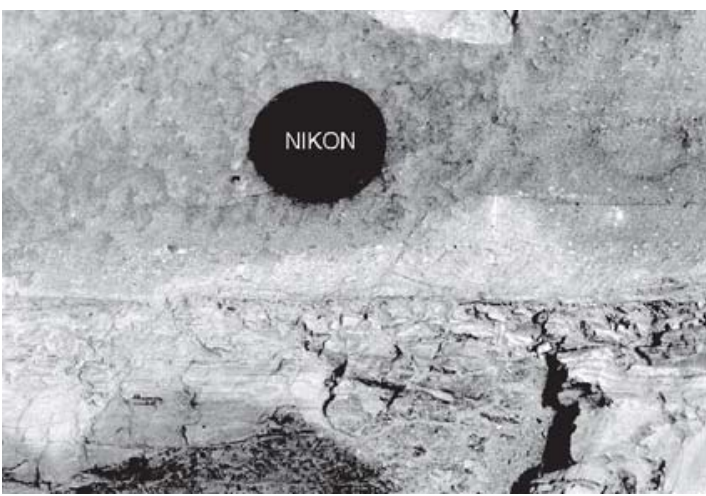

FIGURA 5 - Metarenitos maciços a levemente estratificados (Mar-A2). Intraclastos basais e granodecrescência ascendente.
Zona de Cisalhamento de Pirapora (ZCTP, Figuras 1 e 2), especialmente no seu flanco sul, ocorrem extensas faixas de filitos justapostas aos metarritmitos (Mrt-A3), com os quais exibem contatos gradacionais, e também aos metassiltitos (Msl-A1), com os quais apresentam contatos abruptos em alguns locais. O tectonismo rúptil posterior parece ter sido o responsável pela ocorrência desta litofácies também no flanco norte da referida zona de cisalhamento na localidade de Piraporinha (Figura 2), onde está em contato com rochas granitóides e com associações de litofácies aqui consideradas estratigraficamente superiores (associação clastoquímica transicional). Em condições normais, os filitos incluídos nesta litofácies apresentam estratificação do tipo plano-paralela e representam uma passagem gradual dos níveis pelíticos verificados na litofácies anterior (Mrt-A3) para níveis mais espessos e definidos.

- Metargilitos maciços (Msl-A5). A litofácies compreende níveis de metargilitos maciços, geralmente caolinizados em afloramento, com ocorrência, dimensões e espessuras restritas (provavelmente algumas poucas dezenas de metros) limitando sua representação em mapa. Os metargilitos estão sobrepostos em contato gradacional aos filitos anteriormente descritos (Figura 12). As cores de alteração vão de cinza esverdeado claro a amarelo esbranquiçado.

\subsection{Associação de litofácies B - siliciclástica inter-} mediária

A associação de litofácies B - siliciclástica intermediária tem ocorrência restrita à porção norte da área de estudo (Domínio Votoratim), constituindo uma faixa contínua de orientação NE-SW, a partir da localidade de Santa Helena (sudeste de Votorantim, Figura 1). Nesta associação foram reconhecidas três litofácies, descritas a seguir.

- Metassiltitos laminados e maciços (Msl-B1, Figura 1). Esta litofácies inclui extensas camadas de metapelitos finos a muito finos, cuja espessura total aparente estimada pode superar $500 \mathrm{~m}$. Caracterizam-se por contínuos níveis argilosos e siltosos a areno-siltosos exibindo estratificação/ laminação plano-paralela, cujas espessuras médias variam de 5 $\mathrm{mm}$ a $10 \mathrm{~cm}$. Os níveis pelíticos mais puros possuem coloração cinza médio a escuro, passando a castanho-avermelhado quando intemperizados, enquanto os níveis silto-arenosos exibem cores mais claras, de cinza claro a amarelado. A litofácies apresenta contatos abruptos e descontínuos com os metarritmitos (Mrt-A3) da associação de litofácies 
subjacente, em relação espacial de topo invertido nas proximidades da cidade de Votorantim. Os contatos são gradacionais com os metarenitos da litofácies B3 sobrejacente (descrita a seguir). Notadamente, há um incremento dos níveis siltoarenosos em direção à litofácies B3. Nesse contexto, entre Salto de Pirapora e a localidade de Santa Helena, são observadas laminações cruzadas de baixo ângulo (amplitudes de 1 a 2 cm), caracterizadas pela concavidade dos sets basais e convexidade para cima dos sets superiores, que se assemelham a feições do tipo hummocky (HARMS et al. 1975 apud WALKER \& JAMES 1992), embora suas dimensões possam ser consideradas reduzidas para tal.

Por outro lado, a passagem dos metassiltitos desta litofácies para os metargilitos maciços da litofácies Msl-B2 (descrita a seguir) não é nítida em escala de afloramento, o que inibiu a individualização destas litofácies no mapa da figura 1. Os contatos são difusos e possivelmente de natureza interdigitada, sugerindo uma possível variação faciológica vertical e lateral (expressa principalmente em termos granulométricos e também pela presença ou ausência de estruturas sedimentares), como representado na seção esquemática da figura 12 . Também não são claras as relações de contato entre esta litofácies e os metassiltitos (Msl-C1) da associação de litofácies $\mathrm{C}$ sobrejacente, o que é discutido oportunamente na descrição daquela associação.

- Metargilitos maciços (Msl-B2, Figura 1). Como acima mencionado, esta litofácies possivelmente representa variação vertical e lateral da litofácies anteriormente descrita, tendo uma distribuição restrita à localidade de Santa Helena, situada a sudeste de

TABELA 1 - Associações de litofácies e prováveis ambientes de sedimentação.

\begin{tabular}{|c|c|c|}
\hline $\begin{array}{l}\text { Associaç̃̃es de } \\
\text { Litofácies }\end{array}$ & Litofácies & $\begin{array}{l}\text { Prováveis ambientes de } \\
\text { sedimentação }\end{array}$ \\
\hline \multirow{3}{*}{$\begin{array}{l}D \text { - Carbonática } \\
\text { impura superior }\end{array}$} & $\begin{array}{l}\text { Fil-D3: filitos laminados } \\
\text { e quartzo filitos }\end{array}$ & \multirow{3}{*}{$\begin{array}{l}\text { Planície de maré (intermaré a } \\
\text { supramaré) - águas muito rasas } \\
\text { dominado por correntes e } \\
\text { oscilações de maré, e possivel } \\
\text { exposição subaérea das porções } \\
\text { superiores. }\end{array}$} \\
\hline & $\begin{array}{l}\text { Mcd-D2: metacalcilutitos } \\
\text { maciços }\end{array}$ & \\
\hline & $\begin{array}{l}\text { Mcd-D1: metadolomitos e } \\
\text { metacalcilutitos dolomíticos } \\
\text { bandados, laminados e maciços }\end{array}$ & \\
\hline & & \\
\hline \multirow{5}{*}{$\begin{array}{c}\text { C - Clasto-química } \\
\text { transicional }\end{array}$} & $\begin{array}{l}F C l-C 5: \text { biotita-clorita filitos } \\
\text { bandados }\end{array}$ & \multirow{5}{*}{$\begin{array}{l}\text { Plataforma rasa de característica } \\
\text { progradante passando a planície de } \\
\text { maré mista (intramaré a } \\
\text { intermaré). } \\
\text { Msl-C1: depósitos plataformais. } \\
\text { Mcd-C2 + Fclx-C5: transição para } \\
\text { sistemas carbonáticos peritidais e } \\
\text { planície de maré. Mcd-C3: "sand } \\
\text { flats", porção distal da planície de } \\
\text { maré e canais de maré (intertidal). } \\
\text { Mcd-C4: "mixed flats", porção mais } \\
\text { proximal da planície de maré. }\end{array}$} \\
\hline & $\begin{array}{l}\text { Mcd-C4: metacalcilutitos } \\
\text { laminados e bandados }\end{array}$ & \\
\hline & $\begin{array}{l}\text { Mcd-C3: metadolomitos, } \\
\text { metacalcilutitos, e } \\
\text { metacalcarenitos dolomíticos } \\
\text { bandados }\end{array}$ & \\
\hline & $\begin{array}{l}\text { Mcd-C2: metamargas } \\
\text { laminadas a bandadas }\end{array}$ & \\
\hline & $\begin{array}{l}\text { Msl-C1: metassiltitos maciços e } \\
\text { laminados }\end{array}$ & \\
\hline \multirow{3}{*}{$\begin{array}{l}\text { B - Siliciclástica } \\
\text { intermediária }\end{array}$} & Mar-B3: metarenitos quartzosos & \multirow{3}{*}{$\begin{array}{l}\text { Plataforma rasa de caráter } \\
\text { progradante, dominada por ondas e } \\
\text { com influência de tempestades. } \\
\text { Msl-B1: lamas plataformais. Msl-B2 } \\
\text { e B3: depósitos de antepraia } \\
\text { (shoreface) }\end{array}$} \\
\hline & $\begin{array}{l}\text { Ms/-B2: metargilitos e } \\
\text { metassiltitos maciços a } \\
\text { laminados }\end{array}$ & \\
\hline & $\begin{array}{l}\text { Ms/-B1: metassiltitos laminados } \\
\text { e maciços }\end{array}$ & \\
\hline \multirow{5}{*}{$\begin{array}{c}A \text { - Siliciclástica } \\
\text { basal }\end{array}$} & Msl-A5: metargilitos maciços & \multirow{3}{*}{$\begin{array}{l}\text { Sucessão Turbidítica. } \\
\text { turbiditos de alta densidade } \\
\text { (distais). Fil-A4 e Msl-A5: turbiditos } \\
\text { de baixa densidade ou deposição } \\
\text { pelágica ou hemipelágica }\end{array}$} \\
\hline & $\begin{array}{l}\text { Fil-A4: filitos laminados a } \\
\text { bandados }\end{array}$ & \\
\hline & Mrt-A3: metarritmitos & \\
\hline & $\begin{array}{l}\text { Mar-A2: metarenitos maciços a } \\
\text { levemente estratificados }\end{array}$ & \multirow{2}{*}{$\begin{array}{l}\text { Plataforma rasa dominada ou } \\
\text { influenciada por ondas ?? } \\
\text { Msl-A1: lamas plataformais ? } \\
\text { Mar-A2: depósitos de canal ? }\end{array}$} \\
\hline & MsI-A1: metassiltitos laminados & \\
\hline
\end{tabular}


Votorantim. Caracteriza-se como uma rocha de coloração cinza claro de tonalidade castanho-amarelada, com textura maciça, no entanto, exibindo localmente foliação tectono-metamórfica (pouco desenvolvida) e pequenas manchas sub-elipsoidais constituídas de mineral opaco geralmente oxidado.

- Metarenitos quartzosos (Mar-B3, Figura 1). Na localidade de Santa Helena, a sudeste de Votorantim, ocorre um corpo de forma alongada e lenticular, com espessura aparente estimada variando entre 100 e 150 m, constituído por metarenitos cujo conteúdo em quartzo é superior a 95\%. A rocha é predominantemente maciça, passando a estratificada em direção aos contatos, que são parcialmente afetados pelo cisalhamento transcorrente, especialmente em determinados trechos na interface com metadolomitos pertencentes a associação de litofácies D, sobrejacente.

Os contatos com litofácies subjacentes (metassiltitos e metargilitos, Msl-B1 e Msl-B2 respectivamente) são gradacionais e aparentemente interdigitados, exibindo ao longo dos mesmos acamamentos ondulados e lenticulares (wavy e lenticular bedding) (Figura 6) que, por sua vez, contêm estruturas sedimentares internas tais como laminações de migração de marcas onduladas (ripple drift cross lamination). Nesses locais, a atitude geral do acamamento sedimentar é N16W/ 88NE, destacando-se níveis mais ou menos contínuos, com espessuras entre 5 e $15 \mathrm{~cm}$, contendo areia fina a média de coloração avermelhada, adjacentes e alternados com níveis mais abundantes e mais espes-

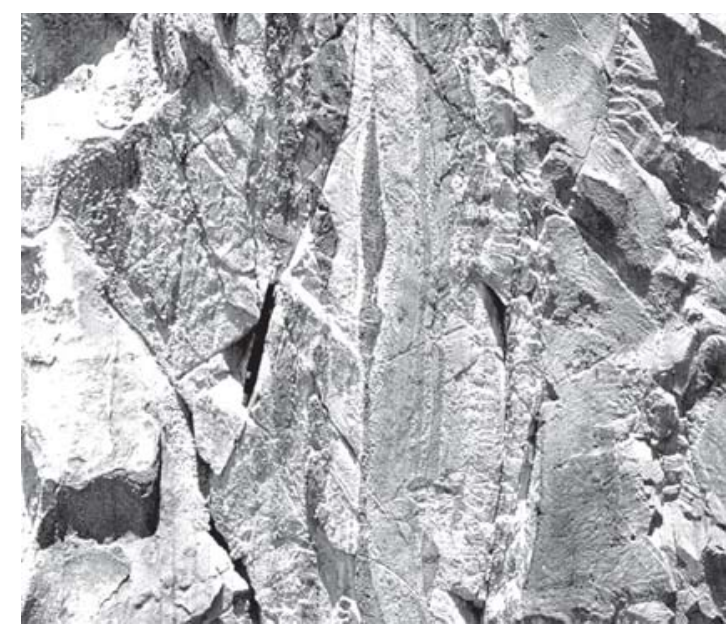

FIGURA 6 - Metarenitos quartzosos (Mar-B3). Acamamento ondulado e lenticular. sos, de coloração mais clara (creme a amarelado) contendo material de granulometria mais fina (siltoarenoso) (Figura 6). As formas do acamamento variam de plano-paralelo a ondulado e lenticular, indicando topo normal para ENE. Os foresets de laminações cruzadas têm espessuras inferiores a 1 cm, concavidade voltada para cima, com contatos inferiores tendendo a tangenciais e superiores truncados, apresentando caráter unidirecional de feições subparalelas à paleocorrente. A atitude média dos planos de foresets é N63E/60 ${ }^{\circ} \mathrm{SE}$, indicando direção de paleocorrente para WSW (Az 250-240 aproximadamente), como mostra o diagrama de roseta da figura 11-A.

\subsection{Associação de litofácies C - clasto-química transicional}

A associação de litofácies C - clasto-química transicional ocorre na porção centro-norte da área de estudo (Domínio Votorantim, Figura 1), particularmente nos arredores da cidade de Salto de Pirapora. A associação inclui metassiltitos maciços e laminados, metamargas, metadolomitos e metacalcilutitos bandados, metacalcarenitos dolomíticos, metacalcários laminados e bandados, e biotita-clorita filitos bandados, descritos a seguir.

Apesar da continuidade física e ausência de contatos bem demarcados com a associação de litofácies B, assim como similaridades com a associação de litofácies D devido à presença comum de rochas clasto-químicas, existem diferenças faciológicas que justificam a individualização desta associação. A leste de sua área de ocorrência, as zonas de cisalhamento de Pirapora e de Moreira provocaram a justaposição das rochas da associação de litofácies $\mathrm{C}$ e os filitos sericíticos e grafitosos (Fil-A4) da associação de litofácies A (Figuras 1 e 2). No entanto, em direção ao norte, as relações de contato com a associação de litofácies B são pouco definidas e sugerem um caráter gradacional. A análise geológico-estrutural, incluindo os indicadores de topo e base das camadas, indica uma posição sobrejacente das rochas metacarbonáticas e filitos bandados da associação de litofácies $C$ em relação aos metassiltitos (Msl-B1) pertencentes à associação de litofácies B. Por outro lado, a associação de litofácies $C$ não exibe contato vertical ou continuidade físico-geográfica com a associação de litofácies $\mathrm{D}$, estando ambas diretamente assentadas em posição sobrejacente à associação de litofácies B. No entanto, a interpretação faciológica sugere um posicionamento que parece refletir a justaposição 
lateral de ambientes ou de porções distintas de um mesmo sistema deposicional, como foi tentativamente representado na seção vertical esquemática da figura 12 e como será discutido posteriormente no item 3.

- Metassiltitos maciços e laminados (Msl-C1, Figuras 1 e 2). Esta litofácies compreende as ocorrências de metassiltitos próximas à cidade de Salto de Pirapora, cujas características e cores de alteração observadas em afloramento assemelham-se àquelas da litofácies B1, entretanto, apresentando sensíveis diferenças. Os perfis geológicos integrados aos dados de poços tubulares profundos não permitiram estimar a espessura aparente para esta litofácies. As rochas aqui incluídas apresentam localmente texturas maciças que evoluem para laminações plano-paralelas em direção às litofácies sobrejacentes, com as quais exibem contatos gradacionais e incluem possíveis variações laterais (contatos com as litofácies C2, C3 e C4 descritas a seguir). A estratificação, quando observada, expressa-se por níveis contínuos de material silto-argiloso com espessuras nunca excedendo 5 ou $6 \mathrm{~mm}$.

- Metamargas laminadas a bandadas (Mcd-C2, Figuras1 e 2). Esta litofácies refere-se às ocorrências de rochas metacarbonáticas impuras, de forma alongada e/ou lenticular descontínuas, distribuídas de maneira esparsa. A espessura provavelmente varia no sentido lateral em decorrência da forma lenticularizada, tendo sido estimados valores máximos entre 150 e $200 \mathrm{~m}$. Os contatos com as demais litofácies são gradacionais e também indicam variações laterais e interdigitamentos. As rochas que constituem esta litofácies caracterizam-se pela alternância de níveis estratificados de material silto-argiloso, cujas espessuras variam de 1 a $2 \mathrm{~mm}$ nos tipos laminados e de 5 a $10 \mathrm{~mm}$ nos tipos bandados, exibindo coloração cinza médio a escuro com tonalidade verde a castanho-avermelhada. A análise petrográfica revelou que o acamamento sedimentar em arranjo plano-paralelo consiste de níveis claros, onde predominam grãos angulosos de quartzo e sericita, que se alternam com níveis compostos por carbonatos e opacos e níveis contendo clorita e opacos, responsáveis pelas tonalidades avermelhadas e esverdeadas respectivamente. Localmente as espessuras dos níveis variam bastante ressaltando-se a granodecrescência ascendente dos níveis quartzosos em direção aos níveis carbonáticos. Este aspecto, observado em nível microscópico, parece refletir as condições ambientais e o arranjo das litofácies em escala meso e macroscópica. Mais restritamente, foram observadas em afloramento, na interface entre níveis claros (predominantemente quartzosos) e níveis de coloração cinza (carbonáticos) em metamargas do tipo bandado, marcas onduladas levemente assimétricas, com amplitudes inferiores a 5 mm e cristas arredondadas. Essas feições foram observadas numa única seção aproximadamente perpendicular ao acamamento, indicando topo para a direção WNW (Figura 11-B).

- Metadolomitos, metacalcilutitos e metacalcarenitos dolomíticos bandados (Mcd-C3, Figuras1 e 2). Na ocorrência da Mina de Salto (sudeste de Salto de Pirapora, contígüa à Zona de Cisalhamento de Moreiras, ZCTM), esta litofácies consiste de um arranjo plano-paralelo no qual predominam camadas de coloração cinza claro, com espessuras variando de 1-2 mm até $8-10 \mathrm{~cm}$, que se alternam com camadas de cor cinza escuro, com espessuras inferiores a $2 \mathrm{~cm}$. Os níveis mais claros geralmente apresentam uma textura mais granular (microesparítica), sendo constituídos predominantemente por carbonatos e quartzo, enquanto os níveis escuros exibem textura criptocristalina (micrítica), onde os minerais opacos são os constituintes principais.

Mesoscopicamente, o contato entre os níveis é bem marcado pelo contraste textural e, em seção delgada, pela passagem abrupta. Todavia, os contatos com as litofácies subjacente (Mcd-C2) e sobrejacente (Fclx-C5), no local, não refletem essa característica, prevalecendo o caráter gradacional. Nas ocorrências da localidade de Ponte Alta (área de mineração desativada, a leste-nordeste de Salto de Pirapora, Figura 2) a litofácies caracteriza-se pela presença mais freqüente de termos psamíticos, apresentando contatos gradacionais a levemente abruptos (onde há maior contraste textural) com as litofácies adjacentes (C1, C2 e C4). Nesse último local a rocha exibe estratificação plano-paralela, constituída pela alternância de níveis mais espessos (de $3 \mathrm{~mm}$ a $6 \mathrm{~cm}$ ) de material silto-arenoso muito fino a fino de coloração cinza claro a amarelado, constituído por carbonatos e quartzo, e de níveis menos espessos (inferior a $1 \mathrm{~mm}$ a $15 \mathrm{~mm}$ ), por vezes, descontínuos, de coloração cinza esbranquiçado, contendo material mais fino (carbonatos). Ocorrem granodecrescência ascendente e variação vertical da espessura dos níveis. Observa-se a presença de diferentes tipos de estruturas sedimentares, importantes para interpretação paleoambiental. Na base desta litofácies os níveis são mais finos e aproxima- 
damente equidimensionais (laminações plano-paralelas), passando a espessuras maiores onde predominam gradativamente os níveis silto-arenosos, atingindo texturas mais maciças a uniformemente estratificadas no topo, onde são observados intraclastos de metarenito muito fino (Figura 7), dispostos paralelamente ao acamamento sedimentar, segundo direções de maior comprimento cujas dimensões variam de 2 a $7 \mathrm{~cm}$. Na porção intermediária, onde a alternância entre os níveis é mais característica, observam-se diversas estruturas sedimentares internas ao acamamento. São laminações de migração de marcas onduladas (ripple drift cross lamination), como mostrado nas figuras 8 e 9, de baixo ângulo, cujo comportamento parece acompanhar as variações verticais acima descritas, observando-se uma tendência à assimetria de formas, e característica estrutural por vezes dissimilar dos sets adjacentes na direção do topo (DE RAAF et al. 1977 apud READING 1996). Localmente, registra-se a ocorrência de laminações cruzadas de baixíssimo ângulo que tendem a paralelizar-se ao plano de estratificação na parte inferior, passando a laminações cruzadas de ângulos maiores, prevalecendo foresets unidirecionais mas também em direções opostas. Os foresets têm espessuras entre 2 e 3 $\mathrm{mm}$ podendo chegar a $1 \mathrm{~cm}$, com mergulhos variando de 5 a $15^{\circ}$ para NNE indicando topos normais das camadas para WNW e direção de paleocorrente para SSW (Figura 11-B). As laminações cruzadas apresentam, em geral, base côncava com limites tangenciais dos foresets; na parte superior, predominam os limites erosivos, por vezes, com feições de truncamento angular e superfícies de reativação e, menos freqüentemente, recobrimentos por material mais fino (mud drapes) ssemelhantes a estruturas do tipo tidal bundles (WALKER \& JAMES 1992), como o exemplo apresentado na figura 9. As espessuras aparentes estimadas para esta litofácies não devem exceder os $200 \mathrm{~m}$.

- Metacalcários (metacalcilutitos predominantemente laminados e bandados) (Mcd- C4, Figuras 1 e 2). As ocorrências referentes a esta litofácies correspondem a corpos alongados e/ou lenticulares situados a leste e nordeste de Salto de Pirapora. Em geral, correspondem a tipos bandados que se caracterizam por faixas claras, com espessuras entre $3 \mathrm{~mm}$ e $4 \mathrm{~cm}$, constituídas de carbonato e quartzo (texturas esparíticas), alternadas a filmes e finos níveis escuros a esverdeados, com espessuras de menos de $1 \mathrm{~mm}$ a $1 \mathrm{~cm}$, compostos por minerais opacos e carbonatos associados a epídoto e quart- zo. Possíveis estruturas de contração foram observadas nos níveis escuros, em escala meso e microscópica, definidas por vênulas aciculares preenchidas por material carbonático, com disposição

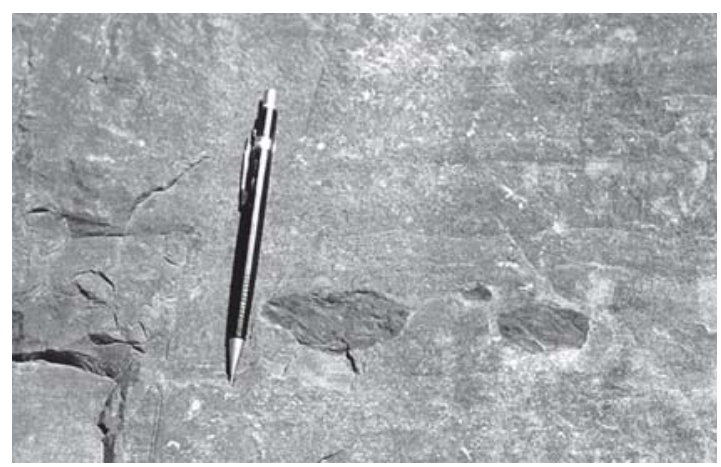

FIGURA 7 - Metadolomitos, metacalcilutitos e metacalcarenitos dolomíticos bandados (Mcd-C3). Intraclastos.

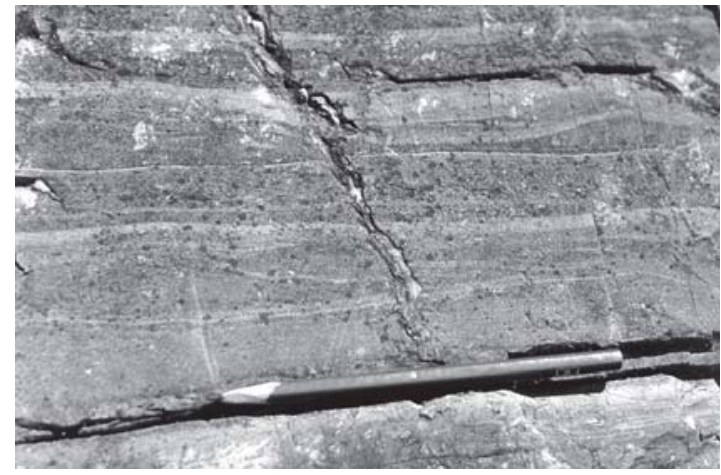

FIGURA 8 - Metadolomitos, metacalcilutitos e metacalcarenitos dolomíticos bandados (Mcd-C3). Laminações de migração de marcas onduladas.

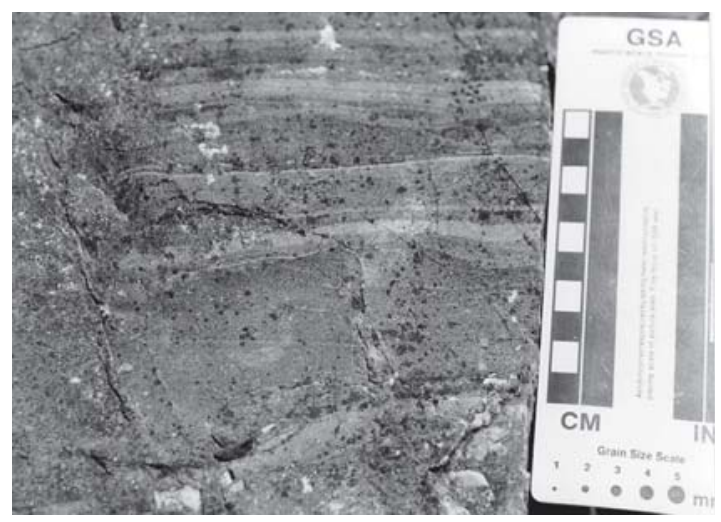

FIGURA 9 - Metadolomitos, metacalcilutitos e metacalcarenitos dolomíticos bandados (Mcd-C3). Laminações cruzadas de migração de marcas onduladas e mud drapes. 
sub-perpendicular ao acamamento e confinadas a esses níveis. Essas feições indicaram topo normal para NW. O contato com a litofácies Mcd-C3, descrita anteriormente, varia de gradacional a levemente abrupto devido a contrastes texturais. Na ocorrência de Ponte Alta (leste-nordeste de Salto de Pirapora) (Figura 2), os metacalcários são mais laminados, e passam gradacionalmente nos contatos inferior e superior para os metacalcilutitos e metacalcarenitos dolomíticos da litofácies C3, respectivamente.

- Biotita-clorita filitos bandados (Fcl-C5) (Figura 2). A única ocorrência desta litofácies registra-se na localidade de Piraporinha, estendendose da Mina de Salto à lavra da Minercal, onde passa vertical e lateralmente às metamargas da litofácies C2 e a metadolomitos e metacalcilutitos da litofácies C3 (Figura 12). Corresponde a uma estreita faixa aflorante com espessura aparente estimada inferior a 80-100 m, apresentando relações de contato difusas (gradacionais a levemente abruptas) e posições estratigráficas variadas em relação às demais litofácies (C1, C2 e C3), podendo representar interdigitamentos. As rochas são constituídas por uma alternância de caráter rítmico entre níveis claros (branco leitoso a cinza muito claro), contendo predominantemente quartzo, e níveis escuros (cinza escuro a esverdeado), contendo principalmente biotita, clorita e epidoto. A espessura dos níveis é bastante variável, desde 1-2 mm até superior a $1 \mathrm{~m}$ nos níveis claros.

Algumas feições centimétricas, observadas na interface de contato entre os níveis, insinuam marcas onduladas levemente assimétricas, indicando topo normal para SSE.

\subsection{Associação de litofácies D - carbonática impu- ra superior}

A associação de litofácies D - carbonática impura superior compreende metadolomitos e metacalcilutitos predominantemente laminados a bandados, metacalcários maciços, e porção bastante restrita e localizada de quartzo-filitos e filitos laminados. O trecho de ocorrência desta associação está limitado à localidade de Santa Helena (Figura 2, Domínio Votorantim, nordeste da área de estudo), onde estão situadas as instalações da fábrica de cimento Votoran I e respectivas áreas de explotação mineral. As relações de contato conjugadas à análise geológico-estrutural, incluindo as indicações de topo e base das camadas, mostram que a associação de litofácies D ocupa posição estratigráfica direta- mente sobreposta aos metassiltitos e metargilitos (Msl-B1 e Msl-B2 respectivamente) e metarenitos (Mar-B3) da associação de litofácies B. Os contatos são predominantemente gradacionais destacandose trechos em que este contato foi afetado pelo cisalhamento transcorrente. Como mencionado anteriormente no item 2.3, não existem relações de contato vertical ou continuidade física entre as associações de litofácies C e D, que, no entanto, apresentam similaridades litofaciológicas, cujas relações de contato (gradacional) com a associação de litofácies B subjacente sugerem a justaposição lateral de ambientes, que poderiam ser partes integrantes de um mesmo sistema deposicional. As litofácies da associação D - carbonática impura superior são descritas a seguir.

- Metadolomitos e metacalcilutitos dolomíticos bandados, laminados e maciços. (Mcd- D1) (Figura 1). A presente litofácies diz respeito às ocorrências da Mina Baltar e do Pastinho, onde ocorrem corpos alongados e/ou lenticulares com espessura aparente estimada em 200-400 m. Apresenta sensíveis variações texturais traduzidas pelos tipos mencionados acima, que aparentemente refletem flutuações nas condições de deposição.

Os tipos laminados e bandados são predominantes, caracterizando-se pela alternância de níveis de coloração cinza médio a escuro, de textura predominantemente micrítica, e de níveis de coloração cinza claro, onde as texturas predominantes são esparíticas. A espessura de cada nível é bastante variável (de 1-2 mm até $50-60 \mathrm{~cm}$ ) ao longo dos afloramentos, prevalecendo os níveis de granulometria mais fina. Os contatos entre os níveis são eminentemente gradacionais, assim como em relação à litofácies sobrejacente (D2), composta por metacalcários, onde observa-se granodecrescência ascendente e aumento progressivo da quantidade e da continuidade das lentes de metacalcário em direção ao topo. Na Mina do Baltar, os contatos entre os metadolomitos e as lentes de metacalcário apresentam tênues e descontínuas ondulações centimétricas, marcadas pela concentração de material fino de coloração escura, similares a feições do tipo flaser (REINECK \& SINGH 1980, COLLINSON \& THOMPSON 1989). Eventualmente, os metadolomitos e metacalcilutitos apresentam textura maciça e, em alguns locais, exibem aspecto brechóide, com vênulas aciculares preenchidas por material carbonático, similares às feições descritas na 
litofácies C4, que poderiam corresponder a estruturas de contração.

Na porção inferior da Mina Baltar (entre cotas altimétricas de 510 e $495 \mathrm{~m}$ ), foram observadas laminações de migração de marcas onduladas (ripple drift cross lamination), cujas amplitudes variam entre 3 e $4 \mathrm{~mm}$. As observações foram efetuadas em seção vertical aproximadamente longitudinal ao plano do acamamento que, no local, apresenta atitude média N58E/48NW. As laminações indicaram topo normal para a direção NNW, com foresets submilimétricos tendo atitude média N25E/38NW. Na mesma localidade, também foram observadas laminações cruzadas de baixo ângulo, indicando truncamento por ondas. A amplitude da referida estrutura é de cerca de $15 \mathrm{~mm}$, e o acamamento sedimentar tem atitude N87E/ $77 \mathrm{NE}$.

- Metacalcários maciços (Mcd- D2) (Figura 1). Esta litofácies corresponde essencialmente às rochas de coloração escura (preta) e composição predominantemente calcítica, com textura maciça (micrítica), aflorantes nas Minas Baltar, da Placa e do Pastinho (sudeste de Votorantim), cuja espessura aparente estimada não deve exceder os 100 m. São rochas extremamente homogêneas, não sendo observadas estruturas sedimentares. Os contatos são gradacionais com os metadolomitos da litofácies subjacente (D1) e com os filitos da litofácies sobrejacente (D3) descritos a seguir.

- Filitos laminados e quartzo filitos. (Fil- D3) (Figura 1). Na ocorrência da Mina da Placa, afloram filitos de textura microcristalina de cor escura (preto), que apresentam laminações plano-paralelas com extrema uniformidade de espessuras (de 2 a $3 \mathrm{~cm}$ ). Entre os níveis pelíticos alternam-se níveis mais quartzosos de textura ligeiramente mais grossa,

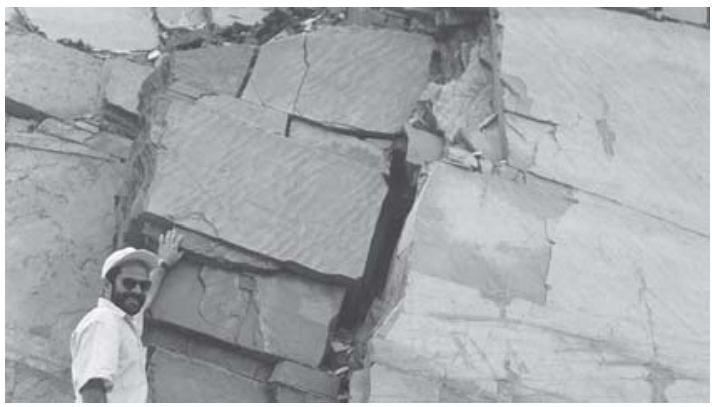

FIGURA 10 - Filitos laminados e e quartzo filitos (FilD3). Marcas onduladas assimétricas. onde sobre o plano de acamamento sedimentar são observadas marcas onduladas de tipos distintos. Marcas onduladas assimétricas de cristas arredondadas ocorrem com padrão mais ou menos contínuo e sinuoso, fora de fase em plano, com amplitudes máximas não ultrapassando 1 cm e comprimentos de onda da ordem de 4 a 5 cm (Figura 10); tais feições indicam inversão do topo da camada para NW, e sentido da paleocorrente, inferido a partir do caimento da linha hipotética transversal à direção das cristas e da direção dos flancos montan-
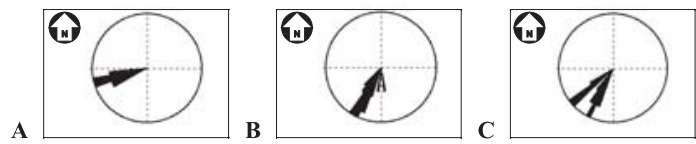

FIGURA 11 - Diagramas de rosetas indicando as direções de paleocorrentes observadas na área de estudo. A associação de litofácies B, B - associação de litofácies C, C - associação de litofácies D.
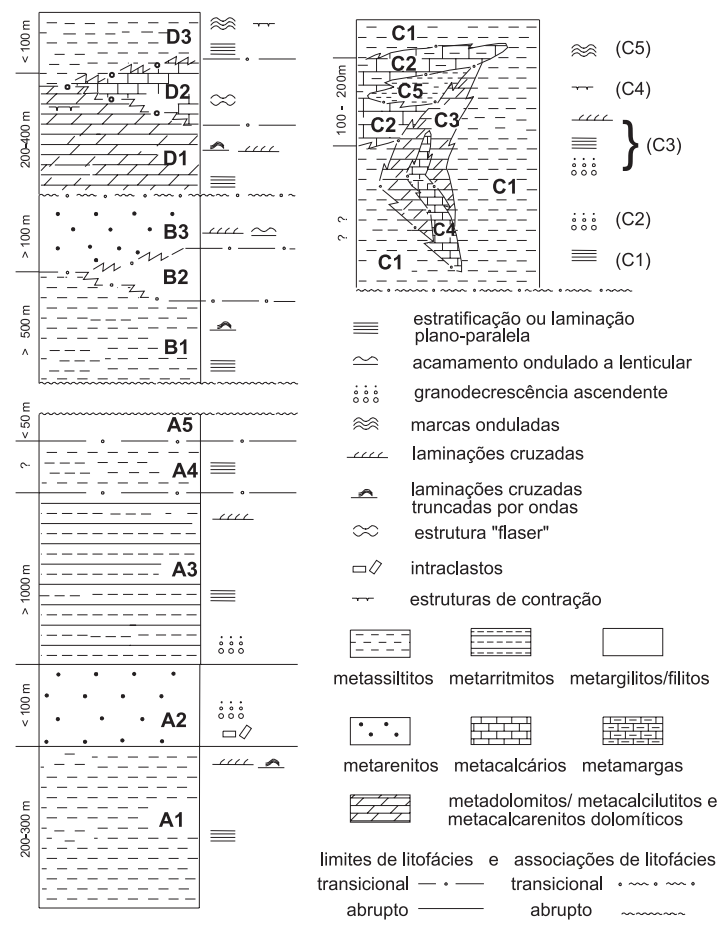

FIGURA 12 - Seção vertical esquemática mostrando as relações entre as diferentes litofácies e associações de litofácies identificadas nas rochas do Grupo São Roque, sudeste do Estado de São Paulo. Indicação das estruturas sedimentares ocorrentes e de algumas espessuras aparentes estimadas a partir de perfis geológicos conjugados a dados de poços tubulares profundos. 
tes, para SW (Az 220 aproximadamente). Também são observadas marcas onduladas de perfil simétrico apresentando cristas arredondadas e mais contínuas, com padrão retilíneo em planta. As amplitudes são inferiores a $5 \mathrm{~mm}$ e os comprimentos de onda situam-se entre 7 e $8 \mathrm{~cm}$.

Parte dos quartzo-filitos (ou mesmo, filitos miloníticos) aflora nas adjacências da Zona de Cisalhamento de Moreiras (ZCTM, Figura1) apresentando-se em afloramento e em seção delgada intensamente afetados por esta, correspondendo a porções milonitizadas desta litofácies.

\section{DISCUSSÃO}

As descrições efetuadas acima, integradas às análises petrográficas e aos resultados obtidos pela análise estrutural e tectônica, conduzem a interpretações distintas para cada uma das associações de litofácies caracterizadas no presente trabalho.

Características sedimentares, geometria e relações de contato entre as diferentes litofácies sugerem que a porção superior da associação de litofácies A - siliciclástica basal corresponde a um contexto deposicional de águas profundas, no qual a sucessão compreendida pelas litofácies A3, A4 e A5 corresponderia a uma sucessão turbidítica. Os metarritmitos (Mrt-A3) que incluem intercalações cíclicas de metarenitos com granodecrescência ascendente na base, seguidos de estratificações e laminações plano-paralelas e laminações cruzadas do tipo climbing na interface com camadas pelíticas, representariam fluxos gravitacionais de massa representados por correntes de turbidez de alta densidade em condições possivelmente distais. Em direção ao topo, correspondendo aos filitos e metargilitos maciços (litofácies A4 e A5, respectivamente), a sucessão passaria a turbiditos de baixa densidade, ou poderia ainda representar a intercalação de processos de decantação num contexto de deposição pelágica ou hemipelágica. Tal contexto é bastante similar àquele sugerido por IG/SMA (1990), significando portanto condições de aprofundamento batimétrico e subida relativa do nível do mar.

No entanto, as litofácies A1 e A2, posicionadas na porção inferior da associação, compreendendo os metassiltitos com laminações cruzadas de baixo ângulo e de truncamento de ondas no topo, sucedidos em contato abrupto por metarenitos com intraclastos basais e granodecrescência ascendente, aparentemente integram um contexto deposicional de águas mais rasas. Essas litofacies foram aqui interpretadas como parte da associação de litofácies A - siliciclástica basal dada à sua contigüidade físico-geográfica e aparente ausência de descontinuidade estratigráfica em relação às litofácies A3 e A4, com as quais estão em contato. De forma especulativa, poder-se-ia dizer que as feições observadas são indicativas de que os metassiltitos (Msl-A1) representariam uma sucessão de plataforma rasa (lamas plataformais), possivelmente num sistema influenciado por ondas e tempestades. Nesse contexto, a presença de corpos de metarenitos quartzosos e feldspáticos (Mar-A2), localmente exibindo termos conglomeráticos e intraclastos basais, poderia ser interpretada como depósitos de canal, não sendo possível precisar, no entanto, se tais depósitos estariam associados a um perfil regressivo, de descida relativa do nível do mar. As feições características da associação de litofácies $B$ - siliciclástica intermediária indicam condições de deposição de uma plataforma rasa de caráter progradante, possivelmente dominada por ondas e com influência de tempestades. Os metassiltitos da litofácies B1 (Msl-B1), nos quais predominam laminações plano-paralelas, mas contendo laminações cruzadas truncadas por ondas similares a hummockys, apesar de suas reduzidas dimensões, poderiam constituir lamas plataformais situadas próximas ou pouco acima do nível de base das ondas. Os metarenitos da litofácies B3 e metargilitos maciços da litofácies B2 podem representar os depósitos de uma antepraia (shoreface) com indícios de progradação sobre a associação de litofácies D, onde há transição para um ambiente no qual a influência de fluxos gerados por marés tornase progressivamente relevante, ainda assim, com aspectos indicativos de progradação, como mencionado a seguir. A presença de acamamentos ondulados a lenticulares contendo laminações internas na interface entre a litofácies B1 e B3 indica uma zona de transição entre os sedimentos plataformais e sedimentos depositados em ambiente sujeito à influência de marés. Os trechos em que a litofácies B2 gradaciona ou interdigita-se diretamente com os sedimentos carbonáticos da litofácies D1 podem representar a progradação da shoreface sobre os ambientes vinculados àquela associação.

As informações coletadas, abrangendo as variadas litofácies que compõem a associação de litofácies $C$ - clasto-química transicional, indicam, como a própria denominação adotada sugere, condições de deposição que vão de uma plataforma rasa, com aporte de material carbonático, dominada por ondas e de características progradantes, para um 
ambiente de sedimentação onde prevaleceram os processos associados a fluxos determinados por marés (intramaré passando a intermaré). As litofácies aqui incluídas (em especial, C2, C3, C4 e C5), notadamente, apresentam geometrias lenticulares, além de variações laterais e verticais entre si, que podem estar associadas a variações batimétricas e à quantidade de aporte sedimentar. Nesse contexto, os metassiltitos da litofácies C1 e as metamargas correspondentes à litofácies C2, constituiriam depósitos plataformais propriamente ditos. Parte desta última litofácies (C2), associada à litofácies C5 (biotita-clorita filitos bandados), onde são observadas granodecrescências ascendentes, marcas onduladas e feições do tipo flaser, podem representar a passagem do contexto de plataforma rasa para ambientes de sedimentação associados a sistemas carbonáticos perimaré ou de planícies de maré (READING 1996, WALKER \& JAMES 1992).

As constituições granulométricas e estruturas sedimentares observadas nas litofácies C3 e C4 evidenciam ambientes de sedimentação dominados por ondas e marés com características intermaré, correspondendo a uma transição de porções inferiores para porções superiores de uma planície de maré (sand flats para mixed flats). Segundo WALKER \& JAMES (1992), sand flats ocupam a porção distal da maioria das planícies de maré, onde a velocidade da corrente é menor, exibindo laminações cruzadas, enquanto as camadas de lama tornam-se mais abundantes em direção ao continente, na medida em que se afastam dos canais de maré, configurando mixed flats. Ainda que sejam tênues evidências, as possíveis estruturas de contração verificadas na litofácies C4, situada no topo desta associação, teriam origem subaquosa, corroborando a hipótese de lâminas d'água menores. COLLINSON \& THOMPSON (1989) assinalam a presença de gretas de sinérese (shrinkage cracks) em sedimentos argilosos ricos em carbonatos, principalmente onde as camadas são pouco espessas, como é o caso dos metacalcários laminados e bandados da litofácies C4.

As estruturas sedimentares observadas, conjugadas à geometria e relações de contato entre as litofácies (espessuras menores, formas lenticulares, contatos gradacionais com feições características), indicam que a deposição da associação de litofácies D - carbonática impura superior processou-se num ambiente de águas muito rasas dominado por correntes e oscilações de maré, com possibilidade de períodos de exposição subaérea das porções superiores. O referido contexto corresponde provavelmente a uma planície de maré, abrangendo a porção intermaré e alcançando restritamente a zona supramaré. Dessa forma, as litofácies D1 e D2, constituídas respectivamente por metadolomitos e metacalcilutitos dolomíticos predominantemente bandados e laminados e por metacalcários maciços, correspondem em parte a ambientes de sedimentação do tipo mixed flats e, principalmente, ambientes do tipo mud flats. A presença de feições similares a hummockys na base da litofácies D1 pode significar a incursão de ondas de tempestade sobre a planície de maré, associada à característica progradante dos depósitos plataformais e de shoreface (referentes à associação de litofácies B) como mencionado acima. A litofácies D3, contendo marcas onduladas assimétricas e simétricas de oscilações na superfície do acamamento, configura possivelmente as porções de topo do ambiente intermaré (mud flat) passando a supramaré.

Na figura 12, as associações de litofácies C e D são representadas como sucessões verticais de litofácies dispostas paralelamente em seção estratigráfica esquemática. Tal disposição procura refletir uma possível justaposição lateral de ambientes ou de porções distintas de um mesmo sistema deposicional. Note-se que as relações de campo indicam que, apesar de não haver contigüidade físicogeográfica entre as associações $\mathrm{C}$ e $\mathrm{D}$, ambas são sobrejacentes à associação de litofácies $\mathrm{B}$, num contexto em que as transições entre as sucessões de litofácies não apresentam grandes descontinuidades, ou seja, predominam contatos gradacionais verticais e laterais, como por exemplo, a passagem lateral dos metassiltitos e argilitos das litofácies B1 e B2, respectivamente, para os metassiltitos da litofácies C1.

Em três associações de litofácies foi possível reconhecer feições indicativas da direção e do sentido das paleocorrentes. Embora a ocorrência dessas feições tenha sido pontual e esparsa, restrita a alguns poucos afloramentos, elas contribuíram para a descrição e interpretação acerca dos ambientes de sedimentação. Para o contexto da área de estudo como um todo, as indicações são de que as paleocorrentes direcionavam-se predominantemente para o sul-sudoeste (Figura 11), já computadas as possíveis inversões de topo das camadas. No entanto, os efeitos do cisalhamento transcorrente e a possibilidade de rotação de blocos tectônicos devem ser considerados, o que significa que tais interpretações devem ser tomadas com ressalvas. Na associação de litofácies $\mathrm{B}$, os indicadores apontam o sentido da paleocorrente para WSW (Figura 11-A), enquanto que, na associação de litofácies C, o sen- 
tido indicado é SSW (Figura 11-B) e, na associação de litofácies D varia de SW a SSW (Figura 11-C). Por outro lado, a relativa consistência das direções de paleocorrentes para o quadrante SW dentro de cada associação de litofácies e entre as mesmas, acrescentada ao fato de que as associações de litofácies $\mathrm{B}, \mathrm{C}$ e D, onde foram efetuadas as medidas, encontram-se todas situadas dentro de um mesmo bloco tectônico (Domínio Votorantim, ao norte da Zona de Cisalhamento de Pirapora, ZCTP, Figura 1) é um aspecto favorável à confiabilidade das interpretações aqui efetuadas.

\section{CONSIDERAÇÕES FINAIS}

O levantamento efetuado visando à caracterização de fácies sedimentares permitiu o reconhecimento de quatro associações de litofácies distintas na parte ocidental do Grupo São Roque, aflorantes no sudeste do Estado de São Paulo. As associações caracterizadas correspondem a ambientes de sedimentação que variam de marinho profundo, passando a marinho raso e marinho restrito ou marinholagunar.

As litofácies A1 e A2, situadas na porção inferior da associação de litofácies A - siliciclástica basal, apresentam características de uma deposição inicialmente em águas mais rasas, que poderia corresponder a uma sucessão regressiva, sem evidências conclusivas para tal. Já as litofácies A3, A4 e A5 sobrejacentes, corresponderiam a depósitos de águas profundas associados a uma aparente subida do nível relativo do mar.

As características faciológicas observadas nas associações de litofácies B, C e D refletem a predominância de um contexto progradacional, desenvolvido em condições de nível do mar constante (possivelmente alto) e significativo aporte sedimentar. A interpretação dos dados e a seção esquemática da figura 12 sugerem uma superfície máxima de inundação (GALLOWAY 1989) entre as associações de litofácies A e B. Especulativamente, pode ser interpretado que o nível relativo do mar poderia ter se mantido alto após a aparente subida registrada na sucessão turbidítica (litofácies A3, A4, e A5) da associação de litófacies A, com progressiva diminuição da batimetria em função do preenchimento do espaço por sedimentação progradante (associação de litofácies B), culminando com o estabelecimento de planícies de maré mistas representadas pelas associações de litofácies C e D. De forma restrita, estas duas associações poderiam ser consideradas como co-genéticas, por aparentemente representarem porções distintas de um mesmo sistema deposicional, que apresentam características diferenciadas em termos de processos sedimentares e de paleogeografia, razão pela qual foram interpretadas no presente trabalho (e representadas graficamente na seção esquemática da figura 12) como justaposição lateral de ambientes. Dessa forma, parte da associação de litofácies C representaria as porções intramaré e intermaré de uma planície de maré, enquanto a associação de litofácies D corresponderia às porções inter a supramaré.

As descrições e interpretações efetuadas acima, integradas ao empilhamento estratigráfico proposto para a área de estudo (Figura12), permitem o estabelecimento de correlações informais entre as associações de litofácies caracterizadas e as designações utilizadas por BERGMANN $(1988,1992)$ e HACKSPACHER (1994) para as possíveis unidades litoestratigráficas do Grupo São Roque em áreas adjacentes, com pequenas variações e algumas ressalvas. Dentro desse contexto, podem ser feitas as seguintes observações:

- a associação de litofácies A - siliciclástica basal corresponderia à Formação Estrada dos Romeiros;

- a associação de litofácies B - siliciclástica intermediária corresponderia, em parte, à Formação Voturuna, ressalvando-se, no entanto, a possibilidade de variações laterais e verticais que implicam possíveis intervalos estratigráficos de transição;

- a associação de litofácies C - clasto-química transicional, representa provavelmente as referidas variações, que podem estar relacionadas a aspectos tais como variações batimétricas e possíveis deslocamentos das fácies sedimentares, como indicam as estruturas sedimentares observadas e distribuição espacial das litofácies. Desse modo, a associação de litofácies C poderia representar uma transição da porção superior da Formação Voturuna para a porção mais inferior da Formação Pirapora;

- a associação de litofácies D - carbonática impura superior corresponderia, com ressalvas, à Formação Pirapora. No caso, o contexto deposicional aqui mencionado difere a princípio daquele observado por BERGMANN (1988) na região de Pirapora do Bom Jesus, marcado pela ausência de rochas metavulcânicas associadas a metacalcários de origem algácea.

Alguns aspectos envolvendo a tectônica da área também merecem ser destacados: 
- dobramentos observados em escala métrica a decamétrica, associados à primeira fase de deformação dúctil (Dn), são responsáveis por inversões estratigráficas locais, que, no entanto, podem refletir um comportamento regional. Tal possibilidade é corroborada pela ocorrência da litofácies Mrt-A3 (metarritmitos) em porções opostas e distintas da área de estudo; na extremidade norte no Domínio Votorantim, em situação de topo invertido em relação à associação de litofácies B, e ao sul no Domínio FazendinhaJurupará (Figura 1). Note-se ainda que as seqüências de rochas turbidíticas e micaxistos identificadas por CAMPOS NETO et al. (1990) na Folha Pilar do Sul, correlacionáveis ao Grupo Açungui ao sul, poderiam representar a continuidade dos ambientes deposicionais de águas mais profundas representados pela associação de litofácies A - siliciclástica basal, caracterizada no presente trabalho e aflorante na porção imediatamente ao norte da Zona de Cisalhamento de Taxaquara;

- os trends faciológicos foram significativamente afetados pela tectônica transcorrente, como é o caso de Piraporinha (porção centro-oeste da área de estudo, próximo à cidade de Salto de Pirapora, Figuras 1 e 2), onde a Zona de Cisalhamento de Pirapora justapõe porções das associações de litofácies A e C. Na mesma localidade observamse ainda deslocamentos dos contatos litológicos e, por conseguinte, dos limites de algumas litofácies, provocados por conjugados de falhas associados a regime compressional de orientação NW-SE (FERNANDES DA SILVA 1997, 1998). Deslocamentos nos contatos litológicos entre metarritmitos (Mrt-A3), filitos (Fil-A4) e granitos (Sf) foram também atribuídos a este evento rúptil em localidades situadas na extremidade leste da área estudada, no Domínio Fazendinha-Jurupará.

\section{AGRADECIMENTOS}

O autor gostaria de expressar seus agradecimentos ao Prof. Dr. Claudio Riccomini pela orientação dos trabalhos, críticas e sugestões; ao Instituto Geológico (IG/SMA) pelo apoio financeiro e infraestrutura; à Cristina M. Nunes pelo apoio em diversas etapas do trabalho, incluindo digitação de textos, tabelas e tabulação dos dados estruturais; à CAPES pela concessão de bolsa de estudos, e aos relatores da Revista do Instituto Geológico pela leitura crítica do presente artigo.

\section{REFERÊNCIAS BIBLIOGRÁFICAS}

ALMEIDA, F.F.M. 1955. As camadas de São Paulo e a tectônica da serra da Cantareira. São Paulo: Boletim SBG, 4(2): 23-40.

ALMEIDA, F.F.M.; HASUY, Y.; PONÇANO, W.L.; DANTAS, A.S.L.; CARNEIRO, C.D.R.; MELO, M.S. de; BISTRICHI, C.A. 1981. Mapa Geológico do Estado de São Paulo, Esc. 1:500.000. São Paulo, IPT, v.1, Nota Explicativa.

BERGMANN, M. 1988. Caracterização estratigráfica e estrutural da seqüência vulcano-sedimentar do Grupo São Roque, região de Pirapora do Bom Jesus (SP). Instituto de Geociências, Universidade de São Paulo, São Paulo, Dissertação de Mestrado, 164p.

BERGMANN, M. 1992. Litoestratigrafia e paleoambiente do Grupo São Roque na região do sinclinório de Pirapora(SP) - Revisão. In: SBG CONGRESSOBRASILEIRO DE GEOLOGIA, 37, São Paulo, Boletim Resumos Expandidos, 1: 282-283.

BISTRICHI, C.A. 1982. Geologia do Sinclinório de Pirapora, SP. Instituto de Geociências, Universidade de São Paulo, São Paulo, Dissertação de Mestrado, 126p.

BISTRICHI，C.A.; CARNEIRO, C.D.R.; DANTAS, A.S.L.; PONÇANO, W.L.; CAMPANHA, G.A.C.; NAGATA, N.; ALMEIDA, M.A.; STEIN, D.P.; MELO, M.S. de; CREMONINI, O.A.; HASUI, Y.; ALMEIDA, F.F.M. 1981. Mapa Geológico do Estado de São Paulo, Esc. 1:500.000. São Paulo, IPT.v.2.

CAMPOS NETO, M.C.; BERGMANN, M.; SIGA, Jr., O; FIGUEIREDO, M.C.H. 1990. Geologia da Folha Pilar do Sul, 1:25.000. Relatório IGUSP/PRO-MINÉRIO (inédito), V.1, Geologia, 161p.

CARNEIRO, C.D.R. 1983. Análise estrutural do Grupo São Roque na faixa entre o pico do Jaraguá e a serra dos Cristais, SP. Instituto de Geociências, Universidade de São Paulo, São Paulo, Tese de Doutoramento, 155p. 
CARNEIRO, C.D.R.; HASUI, Y.; NAGATA, N.; LIMA, M.O. de. 1985. Padrões de superposição de estruturas do Grupo São Roque na faixa Jaraguá - Cristais (SP). São Paulo: Revista Brasileira de Geociências, 15 (2): 116-130.

COLLINSON, C.D. \& THOMPSON, D.B. 1989. Sedimentary structures. Unwin Hyman, $2^{\text {nd }}$ Edition, London, 207p.

COUTINHO, J.M.V. 1972. Petrologia do PréCambriano em São Paulo e arredores. São Paulo: Boletim IG-USP, 1: 5-99

DANTAS, E.L.; HACKSPACHER, P.C.; FETTER,A.H.; SATO, K.;PIMENTAL,M.M.;GODOY,A.M. 2000. $\mathrm{Sm} / \mathrm{Nd}$ isotope systematics related to Proterozoic evolution of the Central Ribeira Belt. São Paulo: Revista Brasileira de Geociências, 30(1): 140-143.

FERNANDES DA SILVA, P.C. 1997. Ambientes de sedimentação e tectônica do Grupo São Roque na região entre Pilar do Sul e Votorantim, SP. Instituto de Geociências, Universidade de São Paulo, São Paulo, Dissertação de Mestrado, 127p.

FERNANDES DA SILVA, P.C. 1998. Tectônica rúptil da região entre Pilar do Sul e Votorantim, SP. São Paulo: Revista Brasileira de Geociências, 28 (4): 485 - 494.

FRANCO, R.R. 1958. Contribuição ao conhecimento das rochas termometamórficas da Série São Roque. São Paulo: Faculdade Filosofia Ciências Letras USP, 81 p. (Boletim 189, Mineralogia 14).

GALLOWAY, W.E. - 1989 - Genetic stratigraphic sequences in basin analysis I: architecture and genesis of flooding - surface bounded depositional units. AAPG Bull., 73(2): 125 - 142.

HACKSPACHER, P.C. 1994.. Tectônica transtensiva/ transpressiva e alojamento de rochas plutônicas, a exemplo da Folha Cabreúva (SP) 1:50.000. Instituto de Geociências e Ciências Exatas, Universidade Estadual Paulista, Rio Claro, Tese de Livre Docência, 203p.

HACKSPACHER, P.C.; DANTAS, E.L.; GODOY, A.M.; OLIVEIRA, M.A.F.; FETTER,A.H.;VAN SCHMUS, W.R. 1999. Considerations about the evolution of Ribeira Belt in the São Paulo State - Brazil: from U/Pb geochronology in metavolcanic rocks of the São Roque Group. In: SOUTH AMERICAN SYMPOSIUM ON ISOTOPE GEOLOGY, 2, Carlos Paz, Argentina, Proceedings, 310-313.

HACKSPACHER, P.C.; DANTAS, E.L.; SPOLADORE, A.; FETTER, A.H.; OLIVEIRA, M.A.F. 2000. Evidence of Neoproterozoic backarc basin development in the Central Ribeira Belt, SE Brazil: new geochronological and geochemical constraintsfrom the São Roque - Açungui Groups. São Paulo: Revista Brasileira de Geociências, 30(1): 110-114.

HACKSPACHER, P.C.; GODOY, A.M.; OLIVEIRA, M.A.F. 1991. Tectônica transcorrente e de cavalgamento do sistema de cisalhamento do Sudeste Brasileiro. In: SBG, SIMPÓSIO NACIONAL ESTUDOS TECTÔNICOS, 3, Rio Claro, Boletim, 1:223-230.

HACKSPACHER, P.C.; GODOY, A.M.; OLIVEIRA, M.A.F. 1993. Evolução crustal do Bloco São Roque na região sudeste do Estado de São Paulo. São Paulo: Revista Brasileira de Geociências, 23(3): 260-264.

HASUI, Y. 1973. Tectônica da área das folhas S.Roque e Pilar do Sul. São Paulo. Instituto de Geociências, Universidade de São Paulo, São Paulo, Tese de Livre Docência, 190p.

HASUI, Y. 1975. Geologia da Folha São Roque. São Paulo: Instituto de Geociências, Universidade de São Paulo (Boletim, 6) p. 157-183.

HASUI, Y. 1985. Novo modelo geológico do Vale do Ribeira. S. Paulo. São Paulo. São Paulo: Instituto de Pesquisas Tecnológicas/Pró-Minério. (Relatório IPT n 23742)

HASUI, Y.; HARALY, N.L.E.; MIOTO, J.A.; SAAD, A.R.; CAMPANHA, V.A.; HAMZA, V.M.; GALLI, V.A.; FRANGIPANI, A.; PULEGHINI FILHO, P.A. 1989. Compartimentação estrutural e evolução tectônica do Estado de São Paulo. São Paulo: Instituto de Pesquisas Tecnológicas. 2v. (Relatório IPT nº 27394).

HASUI, Y.; PENALVA, F.; HENNIES, W.T. 1969. Geologia do Grupo São Roque. In: SBG, CONGRESSO BRASILEIRO DE GEOLOGIA, 23, Salvador, Anais, 1: 101-134. 
HASUI, Y. \& SADOWSKI, G.R. 1976. Evolução geológica do pré-cambriano na região sudeste do Estado de São Paulo. São Paulo: Revista Brasileira de Geociências, 6 (3): 180 - 200.

HASUI, Y.; SADOWSKI, G.R. \& CARNEIRO, C.D.R. 1976. Considerações sobre a estratigrafia do pré-cambriano na região de São Paulo. São Paulo: Instituto de Geociências, Universidade de São Paulo (Boletim, 9) p. 107-113.

HENNIES, W.T.; HASUI, Y.; PENALVA, F. 1967. O falhamento transcorrente de Taxaquara. In: SBG, CONGRESSOBRASILEIRODE GEOLOGIA, 21, Curitiba, Anais: 159-168.

IG/SMA - INSTITUTO GEOLÓGICO/SECRETARIA DE MEIO AMBIENTE DO ESTADO DE SÃO PAULO. 1990. Mapeamento geológico da Folha Salto de Pirapora(SP), escala 1:50.000. Relatório Técnico IG/SMA/SP (inédito), v.1, 76p.

JULIANI, C. 1993. Geologia, petrogênese e aspectos metalogenéticos dos Grupos Serra do Itaberaba e São Roque na região das serras do Itaberaba e da Pedra Branca, NE da cidade de São Paulo, SP. Instituto de Geociências, Universidade de São Paulo, São Paulo, Tese de Doutoramento, 694p.

JULIANI, C.; BELJAVSKIS, P. \& SCHORSCHER, H.D. 1986. Petrogênese do vulcanismo e aspectos metalogenéticos associados: Grupo Serra de Itaberaba na região de São Roque(SP). In: SBG CONGRESSO BRASILEIRO DE GEOLOGIA, 34, Goiânia, Anais, 2: 730-750.

JULIANI, C.; HACKSPACHER, P.C.; DANTAS, E.L.; FETTER, A.H. 2000. The mesoproterozoic volcano-sedimentary Serra do Itaberaba Group of the Central Ribeira Belt, São Paulo State, Brazil: implications for the age of the overlying São Roque Group. São Paulo: Revista Brasileira de Geociências, 30(1): 82-86.
KNECHT, T. 1943. Estaurolita da Série São Roque. São Paulo: Bol. IGG, 1(2): 165-168.

MIALL, A.D. 1985. Principles of Sedimentary Basin Analysis. $2^{\text {nd }}$ Edition, Springer-Verlag, New York, 490p.

MORAES REGO, L.F. 1930. Estados de São Paulo e Paraná. Rio de Janeiro: Serviço de Fomento à Produção Mineral, 83 p. (SFPM - Relatório Anual do Diretor 1929).

READING, H.G. 1996. Sedimentary environments: process, facies, and stratigraphy. Blackwell, $3^{\text {rd }}$ Edition, Oxford, 688p.

REINECK, H. \& SINGH, I.B. 1980. Depositional sedimentary environments. Springer Verlag, $2^{\text {nd }}$ Edition, New York, 549p.

SANTORO, E. 1984. Geologia Folha Cabreúva, SP. Instituto de Geociências, Universidade de São Paulo, São Paulo, Dissertação de Mestrado, 114p.

STEIN, D.P. 1984. Esboço da evolução geológica précambriana da Folha Pilar do Sul, SP (SF-23-YC-IV-4). Instituto de Geociências, Universidade de São Paulo, São Paulo, Dissertação de Mestrado, 148p.

TASSINARI, C.G.C.; KAWASHITA, K.; VAN SCHMUS, R.; TAYLOR, P.N. - 1988 - As idades das rochas e dos eventos metamórficos da região sudeste do Estado de São Paulo. In: SBG, CONGRESSO BRASILEIRA GEOLOGIA, 35, Belém, Anais, 6: 2840-2853.

WALKER, R.G. \& JAMES, P. 1992. Facies models: response to sea level changes. Geological Association of Canada, St. John’s, 409p.

Endereço do autor:

Paulo Cesar Fernandes da Silva - Instituto Geológico, Secretaria do Meio Ambiente, Av. Miguel Stéfano 3900, CEP 04301-903, São Paulo, SP. Email: paulo.fernandes@igeologico.sp.gov.br. 